\title{
Seed moisture content can be used to accelerate dormancy release during after-ripening of Urochloa humidicola cv. Llanero spikelets
}

\section{Fabiana Lima Abrantes ${ }^{1}$ (D) Nelson Barbosa Machado-Neto ${ }^{1}$ (D) Ceci Castilho Custódio ${ }^{1^{*} \text { (ID }}$}

\author{
${ }^{1}$ Agricultural Sciences College, Universidade do Oeste Paulista (UNOESTE), 19067175, Presidente Prudente, SP, Brasil. E-mail: ceci@unoeste.br. \\ ${ }^{*}$ Corresponding author.
}

ABSTRACT: Increased demand for livestock products is leading to research on more productive pastures adapted to different environments. Urochloa humidicola is a species adapted to low-fertility conditions and to environments occasionally subjected to temporary flooding and with highly dormant seeds at harvest. Mechanical and sulphuric acid $\left(\mathrm{H}_{2} \mathrm{SO}_{4}\right)$ scarification are used to release these seeds from dormancy; although, there are several side effects. Hydrogen peroxide $\left(\mathrm{H}_{2} \mathrm{O}_{2}\right)$ is linked to dormancy release in many crop species. The objective of this research was to characterize the dormancy release and $\mathrm{H}_{2} \mathrm{O}_{2}$ accumulation during one year of storage in dormant spikelets of $U$. humidicola cv. Llanero equilibrated to $4.5 \%$ and $50 \%$ relative humidity $(R H)$ and stored at $20^{\circ} \mathrm{C}$, during which time the seeds had moisture contents (MCs) of 0.03 and $0.1 \mathrm{~g} \mathrm{H}_{2} \mathrm{O} \mathrm{g}^{-1}$ dry weight $(\mathrm{DW})$, respectively. The seeds were evaluated initially and at 3, 6 and 12 months; the seeds from spikelets or just caryopses were evaluated. Germination and dormancy percentage, $\mathrm{H}_{2} \mathrm{O}_{2}$ content, superoxide dismutase (SOD) and peroxidase (PRX) activity were determined. The germination and $\mathrm{H}_{2} \mathrm{O}_{2}$ content increased mainly in the caryopses, and SOD activity increased. Moreover, dormancy and PRX activity decreased during storage. For the first time, it was shown, in U. humidicola cv. Llanero that dormancy release during storage is caused mainly by the accumulation of reactive oxygen species (ROS) in the spikelets even under ultra-dry storage conditions $(4.5 \% \mathrm{RH})$, and this process could be accelerated by seed storage at a $\mathrm{MC}$ of $0.1 \mathrm{~g} \mathrm{H}_{2} \mathrm{O} \mathrm{g}^{-1} \mathrm{DW}$ at $20^{\circ} \mathrm{C}$.

Key words: Brachiaria, germination, oxidative window, ultra-dry storage, ROS

\section{Uso do teor de água em sementes para acelerar a quebra de dormência pós-colheita de cariopses} de Urochloa humidicola cv. Llanero

RESUMO: $O$ aumento da demanda de produtos cárneos tem levado a pesquisas de pastagens mais adaptadas para diferentes ambientes. Urochloa humidicola é uma espécie adaptada a solos de baixa fertilidade e sujeitos a alagamentos ocasionais e que apresentam um alto grau de dormência por ocasião da colheita. Escarificação mecânica e por ácido sulfúrico são normalmente usadas para quebrar a dormência nesta espécie, porém com diversos efeitos colaterais. Peróxido de hidrogênio ( $\left.\mathrm{H}_{2} \mathrm{O}_{2}\right)$ está ligado à quebra de dormência em diversas culturas. $\mathrm{O}$ objetivo deste trabalho foi caracterizar a perda de dormencia e o acúmulo de $\mathrm{H}_{2} \mathrm{O}_{2}$, durante um ano de armazenamento em espiguetas dormentes de $U$. humidicola cv. Llanero, equilibrada a 4,5\% e 50\% de umidade relativa (UR) e estocadas a $20{ }^{\circ} \mathrm{C}$; com um conteúdo de água de 0.03 e $0.1 \mathrm{~g} \mathrm{H}_{2} \mathrm{O} \mathrm{g}^{-1}$ matéria seca (MS), respectivamente. As sementes foram avaliadas inicialmente (tempo zero) e aos três, seis e $12 \mathrm{meses;}$ como espiguetas ou cariopses. Foram avaliadas as percentagens de germinação e dormência, teor de $\mathrm{H}_{2} \mathrm{O}_{2}$ e as atividades de superóxido dismutase (SOD) e peroxidase (PRX). A Germinação e o $\mathrm{H}_{2} \mathrm{O}_{2}$ aumentaram, nas cariopses, bem como a atividade de SOD. A dormência e a atividade de PRX diminuíram durante o armazenamento. Pela primeira vez, demonstrou-se em U. humidicola cv. Llanero, que a liberação da dormência durante o armazenamento é causado principalmente pelo acúmulo de espécies reativas de oxigênio (ROS) em espiguetas mesmo em condições de armazenamento ultra seco (4.5\% UR), e que este processo pode ser acelerado por armazenamento de sementes com teor de água de $0.1 \mathrm{~g} \mathrm{H}_{2} \mathrm{O} \mathrm{g}^{-1} \mathrm{MS}$ a $20^{\circ} \mathrm{C}$.

Palavras-chave: Brachiaria, germinação, janela oxidativa, armazenamento ultra seco, ROS.

\section{INTRODUCTION}

The increasing demand for livestock products is driven by population growth, increased richness and urbanization, especially in developing countries. This global demand is projected to increase by approximately $70 \%$ by 2050 to meet an estimated population of 9.6 billion. The larger part of this demand will be achieved through intensive livestock production (concentrated animal feeding operations) and traditional systems (animals raised in pastures) (FAO, 2018).

In a survey about changes in natural cover and land use in Brazil (IBGE, 2020), from 2010 to 2014 , the area occupied by natural and non-natural pastures decreased, but even though beef production and the number of animals per unit area in Brazil increased during that time, Brazil has the second largest cattle herd (232 million heads); as such, Brazil has again attained the position of the highest global exporter of in natura beef (UDSA, 2018). 
The increase in animal production in Brazil is due to technological advances related to genetics, animal nutrition and pasture quality. Brazilian pastures with Urochloa (syn. Brachiaria) spp. have been increasing in area, mainly because of the robustness and adaptability of these species to a range of both climate and soil conditions (CARDOSO et al., 2014).

Dormancy is defined as a temporary failure of a seed to complete germination under favourable conditions, allowing dispersal in time and space (BEWLEY et al., 2013). Urochloa seeds are characterized as exhibiting non-deep physiological dormancy (PD; BASKIN \& BASKIN, 2014); this is a problem for the seed industry, as they needed to be maintained under storage until dormancy is released and for initial pasture establishment, which is impaired by delays in seedling emergency, leading to problems of weed infestation (MARTINS \& SILVA, 2003).

One of the causes of PD in Poaceae species is the impermeability of the seed coat to oxygen, as noted for seeds of Elymus nutans, Lolium perenne, Leymus chinensis, Avena sativa (LV et al., 2017), Triticum vulgare, Oryza sativa, Zea mays, Panicum miliaceum, Sorghum bicolor, Setaria italica and the Sorghum bicolor x S. sudanensis hybrid (SUN et al., 2018).

Many studies have been conducted to increase the germination of forage grasses either by chemicals such as sulphuric acid $\left(\mathrm{H}_{2} \mathrm{SO}_{4}\right.$; MESCHEDE et al., 2004, USBERTI \& MARTINS, 2007, COSTA et al., 2011) or by mechanical scarification, both of which are commonly used methods applied to seeds with gas-impermeable seed coats, such as those of Urochloa (BRASIL 2009). $\mathrm{H}_{2} \mathrm{SO}_{4}$ easily degrades plant tissue components, especially cellulose and hemicellulose. The derivative ion, sulphate, is a weak ligand that can change locations easily within a system and can react in another region (ALVAREZ et al., 2007). Thus, it is necessary to neutralize residual $\mathrm{H}_{2} \mathrm{SO}_{4}$ to avoid environmental problems; moreover, $\mathrm{H}_{2} \mathrm{SO}_{4}$ has negative effects on the germination of U. humidicola (COSTA et al., 2011; USBERTI \& MARTINS, 2007). $\mathrm{H}_{2} \mathrm{SO}_{4}$ also requires an excessive amount of care to circumvent risks for workers and for the environment as an adequate destination of its residue (ALVAREZ et al., 2007).

Seed germination is associated with water absorption, adequate temperature and oxygen supply (BEWLEY et al., 2013). It is divided into three imbibition phases: Phase I, which occurs because of water potential differences; Phase II, which involves the slowing of absorption, during which time several metabolic reactions occur, leading to the emergence of the primary root; and Phase III, which involves the resumption of water absorption due to the growth of the embryonic axis, degradation of reserve substances and growth of the seedling (BEWLEY et al., 2013). However, dormant seeds do not reach Phase III, even when adequate conditions are supplied. Urochloa seed dormancy can be released by exogenous application of gibberellic acid (GA) (SILVA et al., 2013; SORIGOTTI et al., 2016). Dormancy release occurs when there is a decrease in abscisic acid (ABA) levels and an increase in GA levels, as this hormone promotes the synthesis of $\alpha$-amylase, which is involved in the germination process (DIAZVIVANCOS et al., 2013).

Notably, the mechanisms underlying primary seed dormancy and its regulation after ripening are poorly understood (CHAHTANE et al., 2017). In dry $\left(0.1 \mathrm{~g} \mathrm{H}_{2} \mathrm{O} \mathrm{g}^{-1}\right.$ dry weight (DW)) or ultra-dry $\left(0.03 \mathrm{~g} \mathrm{H}_{2} \mathrm{O} \mathrm{g} \mathrm{g}^{-1} \mathrm{DW}\right)$ sunflower seeds, dormancy release is not associated with complex events ranging from gene transcription to posttranslational modification of proteins because, in this state, the water is tightly linked to macromolecules, preventing the synthesis of new biomolecules (MEIMOUN et al., 2014). Therefore, the reactions triggering the breaking of dormancy of dry seeds are not associated with reactions driven by enzymes but are instead due to oxidative processes associated with reactive oxygen species (ROS).

ROS, such as superoxide anions $\left(\cdot \mathrm{O}^{2-}\right)$, hydrogen peroxide $\left(\mathrm{H}_{2} \mathrm{O}_{2}\right)$, singlet oxygen $\left({ }^{1} \mathrm{O}_{2}\right)$ and hydroxyl radicals $\left(\cdot \mathrm{OH}^{-}\right)$, are the principal triggers of many reactions in cells. They are produced mainly in the respiratory pathway and not only are involved in oxidative damage but also act as signalling molecules. ROS are also involved in many events in cells: elongation, cell death, peroxidation, membrane rupture, lignification and protection against herbivores (FOYER et al. 2017; FOYER \& NOCTOR, 2016; MITTLER, 2017). In dry storage, ROS can weaken seed dormancy, and during this process, the seeds age. The enzymes superoxide dismutase (SOD), catalase (CAT) and ascorbate peroxidase (APX) compose the antioxidant system, which works to remove ROS and protect cells from oxidative damage (CHEN \& ARORA, 2011).

Oxidative stress occurs when the amount of ROS produced is greater than the ability of the organism to eliminate them. ROS production was initially considered the production of only toxic molecules because of the impairment of primary metabolism resulted. However, there are reports in which seed germination is linked to internal ROS 
contents and the activities of the antioxidant system (BAILLY \& KRANNER, 2011; DIAZ-VIVANCOS et al., 2013; GOMES \& GARCIA, 2013; ELMAAROUF-BOUTEAU et al., 2015; FOYER \& NOCTOR, 2016; FOYER et al., 2017; MITTLER, 2017); thus, these molecules also act as signalling molecules in biological processes such as seed germination (BAILLY, 2004). According to BAILLY et al. (2008), germination occurs within an "oxidative window"; if the ROS levels are above this window, the seeds are undergoing oxidative damage, leading to deterioration and loss of germination, but below this window, the amount of ROS is too low to allow germination (BAILLY et al., 2008; FOYER et al., 2017; KUMAR et al., 2015; MITTLER, 2017).

ROS production is beneficial in the process of cell wall loosening because the increase in and release of ROS during germination coincides with the period in which the expanding embryo penetrates the seed coat and becomes exposed to the environment (SCHOPFER et al., 2001). During dry storage $\left(0.03 \mathrm{~g}\right.$ to $\left.0.1 \mathrm{~g} \mathrm{H}_{2} \mathrm{O} \mathrm{g} \mathrm{g}^{-1} \mathrm{DW}\right)$, the accumulation of ROS acts as a signal that regulates cellular activity during the post-maturation period (ORACZ et al., 2007), and breaking dormancy is related to changes in gene expression, which were shown to have been caused by the accumulation of ROS in sunflower seeds (EL-MAAROUFBOUTEAU et al. 2007), but this variation in gene expression does not happen during the after-ripening period because of the low water content when the cytoplasm reaches the glass state (BEWLEY et al., 2013; MEIMOUN et al., 2014). At this moisture content (MC), the growth of microorganisms is prevented only because of chemical reactions (Amadori-Mailard reactions and those involving ROS) happen (BEWLEY et al., 2013).

The accumulation of $\mathrm{H}_{2} \mathrm{O}_{2}$ in many ways is directly related to decreasing amounts of ABA, which can lead to seed germination (BAILLY et al., 2008; EL-MAAROUF-BOUTEAU et al., 2007). The internal content of $\mathrm{H}_{2} \mathrm{O}_{2}$ is related to many phenomena in plants (SIEGEL, 1993) and germination, and exogenous $\mathrm{H}_{2} \mathrm{O}_{2}$ application was shown to induce germination of dormant Arabidopsis seeds by triggering ABA catabolism and by stimulating GA biosynthesis (LIU et al., 2010) and shown to induce seed germination in wild almond (ZEINALABEDINI et al., 2009), pea (BARBA-ESPÍN et al. 2010, 2011) and barley (BAHIN et al., 2011). This was confirmed by the use of diphenyliodonium (DPI), which decreases the production of $\mathrm{O}_{2}^{-}$and; consequently, $\mathrm{H}_{2} \mathrm{O}_{2}$, increasing seed dormancy, while the application of exogenous $\mathrm{H}_{2} \mathrm{O}_{2}$ was shown to reverse the effects of DPI in Arabidopsis completely (LIU et al., 2010).

The objective of this research was to characterize the dormancy release and $\mathrm{H}_{2} \mathrm{O}_{2}$ accumulation in dormant spikelets of $U$. humidicola cv. Llanero equilibrated to conditions of $4.5 \%$ and $50 \%$ relative humidity $(\mathrm{RH})$ and stored at $20{ }^{\circ} \mathrm{C}$ for one year.

\section{MATERIALS AND METHODS}

\section{Seed selection and conditioning}

This experiment was conducted with recently harvested pure seeds of Urochloa humidicola cv. Llanero whose caryopses were more than twothirds filled. Seeds were selected by air flow in a South Dakota (DeLeo, Porto Alegre/RS) seed blower and were $90 \%$ viable according to the tetrazolium test (TZ), and $24 \%$ of seeds germinated.

The selected seed lot was split into two portions. The portions were placed into paper bags that were equilibrated over white silica gel (with orange silica used as an indicator), providing $4.5 \%$ $\mathrm{RH}$, and over a lithium chloride solution (36.4 g of $\mathrm{LiCl}$ in $100 \mathrm{~mL}$ of $\mathrm{H}_{2} \mathrm{O}$ ), providing $50 \% \mathrm{RH}$ (HAY et al., 2008). The MC was determined gravimetrically one week after the seeds were equilibrated; for this, one gram of seeds per treatment (two replicates each) was placed in an oven without air flow at $105 \pm 3$ ${ }^{\circ} \mathrm{C}$ for $24 \mathrm{~h}$ (BRASIL, 2009). The equilibrated seeds were maintained in two hermetic plastic boxes with a rubber seal $(28.5 \times 10.0 \times 21.5 \mathrm{~cm})$ during the storage period of 12 months at $20 \pm 3{ }^{\circ} \mathrm{C}$ with silica gel or lithium chloride, during which time the $\mathrm{MC}$ of the seeds was maintained at $0.03 \mathrm{~g}$ or $0.10 \mathrm{~g} \mathrm{H}_{2} \mathrm{O} \mathrm{g}^{-1}$ DW. The RH was checked using a WP4T Dew Point Potentiometer (Decagon Devices Inc., Pullman, WA, USA) that measures the water potential (MPa), which was subsequently converted to RH (\%).

The seeds were sampled at 90-day intervals throughout one year for evaluation. At each time point the seeds from spikelets were used (the caryopses coated with a lemma, palea and lower glumes) or only the caryopses.

\section{Seed viability}

Seed viability was evaluated by the $T Z$ test according to the methods of (CUSTÓDIO et al., 2012), with 4 subsamples of 25 seeds from each period. Seeds (from the spikelets or just the caryopses) were imbibed for $16 \mathrm{~h}$ on moistened paper (the proportion of moisture was 2.5 times the mass of the dried paper) and then manually cut (longitudinally); 
half of the seeds were immersed in a solution of $0.1 \%$ 2,3,5-triphenyl tetrazolium chloride for $5 \mathrm{~h}$ at $40{ }^{\circ} \mathrm{C}$ in the dark. Afterward, the solution was discarded, the seeds were rinsed, and the embryos were considered viable when the vital parts were coloured red. Results were expressed as the percentage of viable seeds.

\section{Germination}

The germination test was performed for four subsamples of 25 seeds from each period. The spikelets and caryopses were sown onto two paper towels within transparent plastic boxes, which were subsequently kept in a germinator whose temperature alternated between 15 and $35^{\circ} \mathrm{C}$, with an eight-hour photoperiod coinciding with the higher temperature (BRASIL, 2009). Germination was measured every two days for 21 days after sowing, and the seeds were considered germinated when the primary root protrusion reached $2 \mathrm{~mm}$.

At the end of the germination test, the remaining seeds were subjected to a $\mathrm{TZ}$ test, as we sought to determine the percentage of dormant (coloured by TZ) and dead seeds (uncoloured by TZ). Owing the discrepancy between results of the initial TZ coloured seeds and the results of the germination test, we calculated the average of these two results via the formula $\mathrm{D}=\left(\frac{D_{E G}+(T z-G)}{2}\right)$, where $\mathrm{D}$ is the percentage of dormant seeds $(\%), \mathrm{D}_{\mathrm{EG}}$ is the number of viable seeds coloured by $\mathrm{TZ}$ after the germination test, $\mathrm{Tz}$ is the percentage of seeds coloured by TZ (\%) and $\mathrm{G}(\%)$ is the result of the germination test.

During each period, a portion of spikelets and caryopses were subjected to biochemical analysis for quantification of $\mathrm{H}_{2} \mathrm{O}_{2}$, guaiacol peroxidase (PRX) activity and SOD activity.

\section{Hydrogen peroxide quantification}

To quantify the amount of $\mathrm{H}_{2} \mathrm{O}_{2}$, four seed subsamples ( $1 \mathrm{~g}$ each) were frozen in liquid nitrogen, macerated in $3.5 \mathrm{~mL}$ of cold $5 \%$ trichloroacetic acid (TCA), and then centrifuged at $14,000 \mathrm{rpm}$ for 5 minutes at $4{ }^{\circ} \mathrm{C}$. After centrifugation, $800 \mu \mathrm{L}$ of the supernatant was collected, and $200 \mu \mathrm{L}$ of $50 \%$ TCA, $200 \mu \mathrm{L}$ of $10 \mathrm{mM}$ ferrous ammonium sulphate and $100 \mu \mathrm{L}$ of $2.5 \mathrm{mM}$ potassium thiocyanate were added. Measurements were performed via a spectrophotometer at $480 \mathrm{~nm}$. The amount of $\mathrm{H}_{2} \mathrm{O}_{2}$ was expressed in micromoles per gram of fresh mass according to the modified methodology of SAGISAKA (1976).

\section{Enzyme extraction}

Four subsamples of approximately $0.2 \mathrm{~g}$ of dry seeds from each treatment were frozen in liquid nitrogen and then ground with a mortar and pestle. Afterward, 0.1 M sodium phosphate buffer ( $\mathrm{pH} 7.8$ ) containing $0.4 \mathrm{~g}$ polyvinylpyrrolidone and consisting of $2 \mathrm{mM}$ dithiothreitol, $0.1 \mathrm{mM}$ EDTA and $1.25 \mathrm{mM}$ PEG 4000 at $4{ }^{\circ} \mathrm{C}$ was added, after which the contents were mixed thoroughly. Dry seeds were used to measure the enzyme activity present in the coats (palea and lemmas) and in the caryopses in the absence of any de novo synthesis. Extracts were centrifuged at 12,000 $\mathrm{g}$ for 20 minutes, and the supernatant was divided into four aliquots, one of which was used for protein quantitation (BRADFORD, 1976). The remaining aliquots were immediately analysed or stored at $-80^{\circ} \mathrm{C}$ and then used to measure enzyme activity.

\section{Superoxide dismutase (SOD, EC.1.15.11).}

SOD activity was measured according to the method described by MORIYA et al. (2015). One unit of SOD (mg protein ${ }^{-1}$ ) was defined as the enzyme activity capable of inhibiting the photoreduction of nitro blue tetrazolium (NBT) to blue formazan by $50 \%$.

Fifty microlitres of the extract was added to $0.1 \mathrm{M}$ phosphate buffer ( $\mathrm{pH} 7.8$ ) added of 1.3 $\mu \mathrm{M}$ riboflavin, $13 \mathrm{mM}$ methionine and $63 \mu \mathrm{M}$ NBT. Tubes were incubated at $25^{\circ} \mathrm{C}$ for 15 minutes under fluorescent light, after which the absorbance was measured at $560 \mathrm{~nm}$. Tubes containing the same mixture and $50 \mu \mathrm{L}$ of the extraction buffer and without sample extracts were used as controls. The SOD activity data were normalized to the protein content according to the BRADFORD (1976) method and expressed in units of SOD per milligram of protein (LEI et al., 2005).

\section{Peroxidase (PRX, EC. 1.11.1.7)}

Four $100 \mathrm{mg}$ subsamples of seeds were frozen in liquid nitrogen, crushed with a mortar with a pestle, homogenized in $3 \mathrm{~mL}$ of $0.01 \mathrm{~mol} \mathrm{~L}^{-1}$ sodium phosphate buffer ( $\mathrm{pH}$ 6.0) and centrifuged at 12,000 rpm for 25 minutes at $4{ }^{\circ} \mathrm{C}$. The PRX activity was measured by the addition of one microgram of protein adjusted to $100 \mu \mathrm{L}$ of the supernatant in $2.9 \mathrm{~mL}$ of $0.01 \mathrm{~mol} \mathrm{~L}^{-1}$ phosphate buffer (pH 6.0) (ARAÚJO et al., 2005) added of $13 \mathrm{mM}$ guaiacol and $5 \mathrm{mM} \mathrm{H}_{2} \mathrm{O}_{2}$ (MORIYA et al., 2015). The mixture was incubated for 20 minutes at $30{ }^{\circ} \mathrm{C}$, after which its absorbance was measured via a spectrophotometer at $470 \mathrm{~nm}$. The enzyme activity was expressed as A470 $\mathrm{nm}$ per minute per milligram of fresh sample.

\section{Statistical analysis}

The experiment was conducted in accordance with a completely randomized design 
with a factorial arrangement of $4 \times 4$ (seed treatment $\mathrm{x}$ storage period), and the data were subjected to analysis of variance (ANOVA). When significant according to the $\mathrm{F}$ test, the means of the treatments were compared by Scott-Knott test $(\mathrm{p} \leq 0.05)$ via the statistical program SISVAR (FERREIRA, 2014).

\section{RESULTS}

The initial germination of the spikelets was $24 \%$ but increased with increasing storage duration and $\mathrm{RH}$. The spikelets stored with greater water content achieved greater germination faster than those stored with lower water content. Compared with the spikelets, the caryopses exhibited a $141.7 \%$ increase in initial germination, showing that the physical covers of the caryopses constitute a barrier to germination. With respect to the caryopses germination, no difference was detected between the storage environments, and the maximum germination was reached at six months of storage (Table 1). The maximum germination of the spikelets was achieved after 12 months of storage, regardless of the storage $\mathrm{RH}$, but, the dormancy release was faster in the moister environment than under dry conditions. The maximum germination point of the caryopses - nine months - was lower than that of the spikelets, and the difference was attributed to removal of the covers, which caused minor injuries to the caryopses; the wounds resulting from these injuries could serve as gateways for pathogens and might have compromised germination (Table 1).

A decrease in dormancy was achieved after six months of spikelets storage, independent of the RH of the storage environment (Table 2). The dormancy decreased until the third month, when the coats were removed and when the caryopses were isolated. Afterward, there was no difference between them, independent of the use of caryopses or spikelets (Table 2). This finding seems to be associated with an increase in the endogenous content of $\mathrm{H}_{2} \mathrm{O}_{2}$ (Table 3), while the loss of dormancy with the removal of the coverings did not alter the levels of $\mathrm{H}_{2} \mathrm{O}_{2}$ (Table 3).

The SOD activity was initially greater in the spikelets than in the caryopses, but after three months of storage, the removal of the coats of the caryopses increased the SOD activity, which stayed high until the end of the experiment. After six months, samples from the ultra-dry storage conditions $(4.5 \%$ RH) presented high activity (Table 4).

The PRX activity was greater in the spikelets than in the caryopses at the first evaluation (0 storage period). However, in the other periods, no difference was observed between the spikelets and the caryopses. The PRX activity was high for up to 3 months of storage, but it decreased after that (Table 5). A portion of the PRX activity was seemingly initially linked to the seed coat, as shown in Table 5 (month zero).

Antioxidant metabolism, represented by SOD and PRX activity, decreased in the spikelets during the storage period (Tables 4 and 5), and for the caryopses, this also happened, albeit just for PRX. However, the SOD activity in the caryopses increased over time (Table 5).

The maintenance of seeds during afterripening generates ROS, either by ageing or by stress conditions such as high $\mathrm{RH}$ and high temperature. In this paper, seeds were stored in two different environments, one moister $(50 \% \mathrm{RH})$ than the other $(4.5 \% \mathrm{RH})$, at the same temperature. In both cases, the generation of ROS could be related to a gradual increase in germination (Table 1) by dormancy release (Table 2) and an increase in $\mathrm{H}_{2} \mathrm{O}_{2}$ content (Table 3 ).

After 12 months, the maximum values of germination (Table 1) and the minimum dormancy

Table 1 - Germination of spikelets or caryopses of $U$. humidicola cv. Llanero seeds during 12 months in two conditions of storage.

\begin{tabular}{|c|c|c|c|c|}
\hline \multirow[t]{2}{*}{ Seed treatment } & \multicolumn{4}{|c|}{ 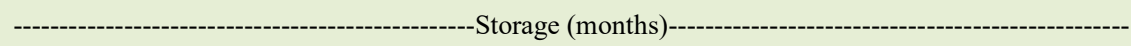 } \\
\hline & 0 & 3 & 6 & 12 \\
\hline & \multicolumn{4}{|c|}{ 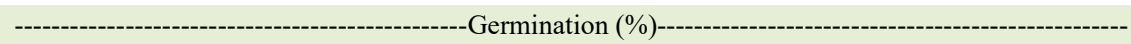 } \\
\hline Spikelet $4.5 \% \mathrm{RH}$ & $24.0 \pm 2.3 \mathrm{bC}$ & $46.0 \pm 8.9 \mathrm{bB}$ & $88.0 \pm 4.9 \mathrm{aA}$ & $92.0 \pm 4.0 \mathrm{aA}$ \\
\hline Spikelet $50 \%$ RH & $24.0 \pm 2.3 \mathrm{bC}$ & $76.0 \pm 4.0 \mathrm{aB}$ & $79.0 \pm 5.7 \mathrm{aB}$ & $95.0 \pm 2.5 \mathrm{aA}$ \\
\hline Caryopses $4.5 \% \mathrm{RH}$ & $58.0 \pm 4.2 \mathrm{aB}$ & $69.0 \pm 8.5 \mathrm{aB}$ & $89.0 \pm 4.1 \mathrm{aA}$ & $77.0 \pm 5.2 \mathrm{bA}$ \\
\hline Caryopses $50 \%$ RH & $58.0 \pm 4.2 \mathrm{aB}$ & $79.0 \pm 2.5 \mathrm{aA}$ & $85.0 \pm 3.4 \mathrm{aA}$ & $74.0 \pm 3.5 \mathrm{bA}$ \\
\hline
\end{tabular}

Means followed by equal letters, lowercase in the column and upper case in the row, do not differ by Scott-Knott test $(\mathrm{P}<0.05)$.

Ciência Rural, v.51, n.1, 2021. 
Table 2 - Dormancy of spikelets or caryopses of $U$. humidicola cv. Llanero seeds during 12 months in two conditions of storage.

\begin{tabular}{|c|c|c|c|c|}
\hline \multirow[t]{2}{*}{ Seed treatment } & \multicolumn{4}{|c|}{ 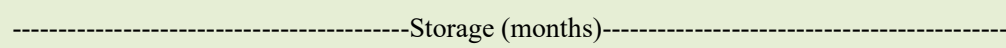 } \\
\hline & 0 & 3 & 6 & 12 \\
\hline & \multicolumn{4}{|c|}{ 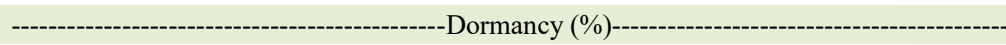 } \\
\hline Spikelet $4.5 \%$ RH & $45.5 \pm 4.6 \mathrm{bA}$ & $43.0 \pm 6.6 \mathrm{aA}$ & $8.0 \pm 3.7 \mathrm{aB}$ & $3.5 \pm 2.9 \mathrm{aB}$ \\
\hline Spikelet $50 \%$ RH & $45.5 \pm 4.6 \mathrm{bA}$ & $15.0 \pm 3.8 \mathrm{cB}$ & $12.0 \pm 3.8 \mathrm{aB}$ & $1.5 \pm 1.5 \mathrm{aC}$ \\
\hline Caryopses $4.5 \%$ RH & $19.5 \pm 2.3 \mathrm{aA}$ & $24.0 \pm 7.2 \mathrm{bA}$ & $4.0 \pm 1.6 \mathrm{aB}$ & $6.5 \pm 3.8 \mathrm{aB}$ \\
\hline Caryopses $50 \% \mathrm{RH}$ & $19.5 \pm 2.3 \mathrm{aA}$ & $11.0 \pm 2.6 \mathrm{cB}$ & $4.0 \pm 1.4 \mathrm{aB}$ & $6.9 \pm 1.8 \mathrm{aB}$ \\
\hline
\end{tabular}

Means followed by equal letters, lowercase in the column and upper case in the row, do not differ by Scott-Knott test $(\mathrm{P}<0.05)$.

(Table 2) were recorded for all seed treatments. For spikelets stored at $50 \% \mathrm{RH}$, there were a faster lack of dormancy (Table 2) and a faster accumulation of $\mathrm{H}_{2} \mathrm{O}_{2}$, differing from those observed in the other treatments after 6 months of storage (Table 3).

When the activity of PRX decreased during storage (Table 5), there was a natural increase in the amount of $\mathrm{H}_{2} \mathrm{O}_{2}$ (Table 3 ).

Germination and dormancy had a strong coefficient of determination under all conditions (Table 6), but there were strong negative correlations (Table 6) in the three situations, with spikelets at $4.5 \% \mathrm{RH}$ and spikelets and caryopses at $50 \% \mathrm{RH}$. In the case of germination and $\mathrm{H}_{2} \mathrm{O}_{2}$, there were moderate correlations for spikelets but not for caryopses, and in the case of germination and SOD, there were moderate correlations for spikelets and a strong correlation for caryopses under both storage conditions. Between germination and PRX, there were moderate correlations for the spikelets but not for the caryopses. At $4.5 \% \mathrm{RH}$, there was a weak correlation between dormancy and $\mathrm{H}_{2} \mathrm{O}_{2}$ for the spikelets and a strong correlation at $50 \% \mathrm{RH}$. No correlations were detected between dormancy and SOD at $4.5 \% \mathrm{RH}$ either for the spikelets or caryopses, but moderate correlations were detected for the spikelets and caryopses stored at 50\% RH. With respect to dormancy and PRX, there was a strong correlation for the spikelets stored at $4.5 \% \mathrm{RH}$ and moderate correlations for other combinations.

\section{DISCUSSION}

The removal of the covers was related to dormancy release, but it was not enough to eliminate the dormancy completely or to increase germination to the maximum in this study, even though the covers were impermeable to gas (LV et al., 2017; SUN et al., 2018); the after-ripening process during storage was also related to this.

The maximum values of germination observed after 12 months might have occurred because seeds with greater moisture have a greater respiration rate than do relatively drier seeds, which means that the former would accumulate more ROS, such as $\mathrm{H}_{2} \mathrm{O}_{2}$, which is a trigger for many reactions,

Table 3 - Hydrogen peroxide accumulation in spikelets or caryopses of $U$. humidicola cv. Llanero seeds during 12 months in two conditions of storage.

\begin{tabular}{|c|c|c|c|c|}
\hline \multirow[t]{2}{*}{ Seed treatment } & \multicolumn{4}{|c|}{ - } \\
\hline & 0 & 3 & 6 & 12 \\
\hline & \multicolumn{4}{|c|}{ - } \\
\hline Spikelet $4.5 \% \mathrm{RH}$ & $1.056 \pm 0.1 \mathrm{aC}$ & $2.113 \pm 0.4 \mathrm{aB}$ & $1.405 \pm 0.2 \mathrm{bC}$ & $4.561 \pm 0.1 \mathrm{aA}$ \\
\hline Spikelet $50 \%$ RH & $1.056 \pm 0.1 \mathrm{aC}$ & $1.713 \pm 0.3 \mathrm{aC}$ & $3.126 \pm 0.5 \mathrm{aB}$ & $4.475 \pm 0.4 \mathrm{aA}$ \\
\hline Caryopses $4.5 \% \mathrm{RH}$ & $0.652 \pm 0.1 \mathrm{aC}$ & $1.398 \pm 0.3 \mathrm{aB}$ & $1.658 \pm 0.3 \mathrm{bB}$ & $4.880 \pm 0.2 \mathrm{aA}$ \\
\hline Caryopses 50\% RH & $0.652 \pm 0.1 \mathrm{aC}$ & $2.407 \pm 0.3 \mathrm{aB}$ & $1.688 \pm 0.4 \mathrm{bB}$ & $4.008 \pm 0.2 \mathrm{aA}$ \\
\hline
\end{tabular}

Means followed by equal letters, lowercase in the column and upper case in the row, do not differ by Scott-Knott test $(\mathrm{P}<0.05)$. 
Table 4 - Superoxide dismutase activity (SOD) in spikelets or caryopses of $U$. humidicola cv. Llanero seeds during 12 months in two conditions of storage.

\begin{tabular}{|c|c|c|c|c|}
\hline \multirow[t]{2}{*}{ Seed treatment } & \multicolumn{4}{|c|}{ 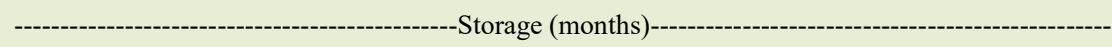 } \\
\hline & 0 & 3 & 6 & 12 \\
\hline & \multicolumn{4}{|c|}{ 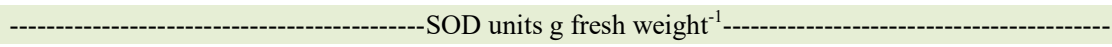 } \\
\hline Spikelet $4.5 \% \mathrm{RH}$ & $13.638 \pm 0.5 \mathrm{aA}$ & $8.618 \pm 0.6 \mathrm{bB}$ & $14.714 \pm 0.7 \mathrm{aA}$ & $8.593 \pm 0.5 \mathrm{cB}$ \\
\hline Spikelet $50 \%$ RH & $13.638 \pm 0.5 \mathrm{aA}$ & $9.466 \pm 1.7 \mathrm{bB}$ & $8.464 \pm 0.4 \mathrm{cB}$ & $8.623 \pm 0.9 \mathrm{cB}$ \\
\hline Caryopses $4.5 \% \mathrm{RH}$ & $7.025 \pm 0.2 \mathrm{bC}$ & $19.459 \pm 0.6 \mathrm{aA}$ & $15.070 \pm 0.3 \mathrm{aB}$ & $19.655 \pm 1.3 \mathrm{aA}$ \\
\hline Caryopses $50 \%$ RH & $7.025 \pm 0.2 \mathrm{bC}$ & $17.851 \pm 1.5 \mathrm{aA}$ & $11.040 \pm 0.3 \mathrm{bB}$ & $16.471 \pm 0.7 \mathrm{bA}$ \\
\hline
\end{tabular}

Means followed by equal letters, lowercase in the column and upper case in the row, do not differ by Scott-Knott test $(\mathrm{P}<0.05)$.

including dormancy release (EL-MAAROUFBOUTEAU \& BAILLY, 2008, EL-MAAROUFBOUTEAU et al., 2015, MITTLER, 2017).

The $\mathrm{H}_{2} \mathrm{O}_{2}$ increase during storage was an effect of a relatively high ROS production and was related to a decrease in the scavenger (PRX) activity during storage, and as a result, a dormancy release occurred during the storage period (after-ripening), followed by the start of the decrease in germination, such as that which occurred for the caryopses in both treatments; this imbalance of the antioxidant system and ROS production is a characterization of oxidative stress (EL-MAAROUF-BOUTEAU \& BAILLY, 2008; MITTLER, 2017).

ROS are related to the balance of hormones, mainly ABA (EL-MAAROUF-BOUTEAU \& BAILLY, 2008; BAHIN et al., 2011; BAILLY \& KRANNER, 2011; BARBA-ESPÍN et al,. 2011; DIAZ-VIVANCOS et al., 2013; EL-MAAROUFBOUTEAU et al., 2015); consequently, ABA is involved in dormancy because during dormancy, the ABA pathway is active and inhibits germination. High amounts of ABA can maintain high levels of scavenger enzymes, resulting in low amounts of ROS during the soaking of dormant seeds (ELMAAROUF-BOUTEAU \& BAILLY, 2008).

According to EL-MAAROUF-BOUTEAU \& BAILLY (2008) and a review written by KUMAR et al. (2015), there is a certain amount of ROS needed for germination, which the authors refer to as an "oxidative window" for germination; below this amount, dormancy is maintained, and above it, seeds will begin to deteriorate. This is closely related to the resistance phase of stress cited by KRANNER et al. (2010).

SOD plays a key role in the antioxidant defence system because it converts $\bullet \mathrm{O}^{2-}$ into $\mathrm{H}_{2} \mathrm{O}_{2}$ and water, thereby affording protection against the deleterious effects of the superoxide radical $\left(\cdot \mathrm{O}_{2}{ }^{2-}\right)$ (MITTLER et al., 2004; GILL et al., 2012). In the present study, SOD activity increased during storage with high seed moisture and with the removal of

Table 5 - Guaiacol peroxidase (PRX) activity in spikelets or caryopses of $U$. humidicola cv. Llanero seeds during 12 months in two conditions of storage.

\begin{tabular}{|c|c|c|c|c|}
\hline \multirow[t]{2}{*}{ Seed treatment } & \multicolumn{4}{|c|}{ 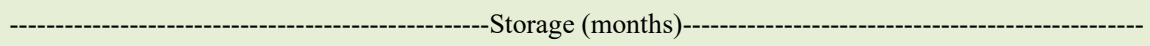 } \\
\hline & 0 & 3 & 6 & 12 \\
\hline & \multicolumn{4}{|c|}{ 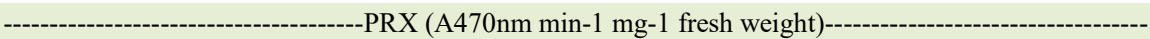 } \\
\hline Spikelet $4.5 \% \mathrm{RH}$ & $0.874 \pm 0.09 \mathrm{bA}$ & $0.937 \pm 0.04 \mathrm{aA}$ & $0.226 \pm 0.01 \mathrm{aB}$ & $0.208 \pm 0.01 \mathrm{aB}$ \\
\hline Spikelet $50 \% \mathrm{RH}$ & $0.874 \pm 0.09 \mathrm{bA}$ & $0.938 \pm 0.07 \mathrm{aA}$ & $0.230 \pm 0.02 \mathrm{aB}$ & $0.232 \pm 0.02 \mathrm{aB}$ \\
\hline Caryopses $4.5 \% \mathrm{RH}$ & $0.673 \pm 0.04 \mathrm{aB}$ & $1.005 \pm 0.03 \mathrm{aA}$ & $0.213 \pm 0.02 \mathrm{aC}$ & $0.240 \pm 0.02 \mathrm{aC}$ \\
\hline Caryopses $50 \%$ RH & $0.673 \pm 0.04 \mathrm{aB}$ & $0.964 \pm 0.05 \mathrm{aA}$ & $0.243 \pm 0.01 \mathrm{aC}$ & $0.224 \pm 0.01 \mathrm{aC}$ \\
\hline
\end{tabular}

Means followed by equal letters, lowercase in the column and upper case in the row, do not differ by Scott-Knott test $(\mathrm{P}<0.05)$. 
Table 6 - Coefficient of determination $\left(\mathrm{R}_{2}\right)$ and Pearson correlation (r) between germination (G\%) and dormancy(D) with Hydrogen peroxide $\left(\mathrm{H}_{2} \mathrm{O}_{2}\right)$, Superoxide Dismutase activity (SOD) and Peroxidase activity (PRX).

\begin{tabular}{|c|c|c|c|c|c|c|c|c|}
\hline & \multicolumn{4}{|c|}{-------------------------------4.5\%------------------------------- } & \multicolumn{4}{|c|}{----------------------------------50\%--------------------------------- } \\
\hline & \multicolumn{8}{|c|}{--------------------------------------------------------------------Spikelets-------------------------------------------------------------------- } \\
\hline & \multicolumn{2}{|c|}{ 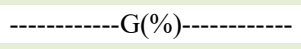 } & \multicolumn{2}{|c|}{---------------D-------------- } & \multicolumn{2}{|c|}{ 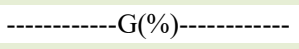 } & \multicolumn{2}{|c|}{ 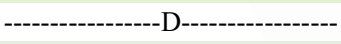 } \\
\hline & $\mathrm{R}_{2}$ & $\mathrm{r}$ & $\mathrm{R}_{2}$ & $\mathrm{r}$ & $\mathrm{R}_{2}$ & $\mathrm{r}$ & $\mathrm{R}_{2}$ & $\mathrm{r}$ \\
\hline $\mathrm{D}$ & $0.97^{* *}$ & $-0.701^{*}$ & & & $0.99^{* *}$ & $-0.868^{*}$ & & \\
\hline $\mathrm{H} 2 \mathrm{O} 2$ & 0.6 & $0.534^{*}$ & 0.59 & $-0.488^{*}$ & 0.83 & $0.634^{*}$ & 0.85 & $-0.73^{*}$ \\
\hline SOD & 0.12 & $0.608^{*}$ & 0.001 & -0.103 & $0.97^{* *}$ & $0.699^{*}$ & $0.97^{* *}$ & $-0.56^{*}$ \\
\hline PRX & $0.94^{*}$ & $-0.656^{*}$ & $0.99^{* *}$ & $0.841^{*}$ & 0.64 & $-0.532^{*}$ & 0.67 & $0.554^{*}$ \\
\hline \multicolumn{9}{|c|}{ 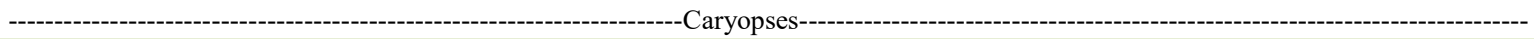 } \\
\hline $\mathrm{D}$ & $0.81^{*}$ & -0.277 & & & $0.91^{*}$ & $-0.609^{*}$ & & \\
\hline $\mathrm{H} 2 \mathrm{O} 2$ & 0.39 & 0.147 & 0.57 & -0.498 & 0.41 & 0.371 & 0.60 & -0.479 \\
\hline SOD & 0.52 & $-0.701^{*}$ & 0.20 & 0.214 & 0.57 & $-0.777^{*}$ & 0.50 & $0.634^{*}$ \\
\hline PRX & 0.69 & 0.21 & $0.98^{*}$ & $0.613^{*}$ & 0.26 & 0.146 & 0.62 & $0.549^{*}$ \\
\hline
\end{tabular}

Coefficient of determination $\left(\mathrm{R}_{2}\right)$ and Pearson Correlation $(\mathrm{r})-^{*}(\mathrm{P}<0.1),{ }^{* *}(\mathrm{P}<0.05){ }^{* * *}(\mathrm{P}<0.01)$ significance by Student's $t$ test.

the palea, lemma and lower glumes, exposing the caryopses to the air; this exposure could generate $\cdot \mathrm{O}^{2-}$, so the first enzyme of the detoxification system (SOD) acts to prevent deterioration, which can result in seed death (MITTLER et al., 2004; MORIYA et al., 2015).

$\mathrm{H}_{2} \mathrm{O}_{2}$ accumulation is involved in dormancy release because it activates ABA-degrading enzymes (BARBA-ESPÍN et al. 2010, 2011). In rice, the activity of this enzyme both in grain and in seed coat were different, as it decreased in the seed coats (HANUMANTHAPPA et al., 2015).

During storage, the enzyme reservoir was exhausted, as there was a notable decrease in the later measurements. This can be explained by the dry state of the seeds, in which no synthesis is possible because of the glass state. Therefore, the enzymes that were stored during the final steps of maturation could be degraded during storage, allowing conditions for an imbalance in ROS accumulation/degradation that could lead to two events: signalling for dormancy release or degradation of biochemical structures that will lead to cell death (FOYER et al. 2017; KRANNER et al., 2010; MITTLER, 2017).

PRXs are able to remove $\mathrm{H}_{2} \mathrm{O}_{2}$; thus, a high concentration/activity of PRX may reduce the level of $\mathrm{H}_{2} \mathrm{O}_{2}$, maintaining dormancy. Here, the decreasing activity of PRX during storage was related to an increase in germination. In transgenic Arabidopsis lines overexpressing the 1-Cys PER1 protein from barley (Hordeum vulgare) or presenting reduced AtPER1 accumulation because of antisense or RNA interference, there was a correlation between PRX levels and the duration needed to trigger germination, as reported by HASLEKAS et al. (2003). The increase in $\mathrm{H}_{2} \mathrm{O}_{2}$ content per se is a signal of dormancy release that differs between dormant and non-dormant seeds, and $\mathrm{H}_{2} \mathrm{O}_{2}$ increases with imbibition (EL-MAAROUFBOUTEAU et al., 2007).

Conversely, compared with those immersed in water, pea seeds immersed in $\mathrm{H}_{2} \mathrm{O}_{2}$ for $24 \mathrm{~h}$ (BARBA-ESPÍN ET AL. 2012) presented an increase in the percentage of germination and seedling growth, and results were dose dependent; e.g., until a certain concentration, there was positive input, and afterward, a decline in germination was observed, which fits perfectly with the oxidative window (EL-MAAROUF-BOUTEAU \& BAILLY 2008). Response of pea seeds to increasing doses of $\mathrm{H}_{2} \mathrm{O}_{2}$ included an increase in $\mathrm{H}_{2} \mathrm{O}_{2}$-induced proteins (BARBA-ESPÍN et al. 2010, 2011), which are involved in signalling, plant development, elongation and cell division, as well as in the activity of APX, POX and ascorbate oxidase (AAO), reducing the levels of ABA and cytokinin (BARBAESPIÍN et al., 2010).

Storage in an environment of relatively high moisture $(50 \% \mathrm{RH})$ increased the dormancy release 
in $U$. humidicola cv. Llanero seeds, and this method is safer than scarification with $\mathrm{H}_{2} \mathrm{SO}_{4}$ and better than mechanical scarification, for which germination starts to decrease after nine months. Conversely, storage of very dry seeds maintains dormancy and quality. $\mathrm{H}_{2} \mathrm{O}_{2}$ determination may help to decide what storage time is adequate to remove and sell seeds.

\section{CONCLUSION}

It was demonstrated, for the first time, that dormancy release, in $U$. humidicola $\mathrm{cv}$. Llanero, during storage was caused mainly by the accumulation of ROS in the spikelets even under ultra-dry storage conditions $(4.5 \% \mathrm{RH})$, and this process could be accelerated by seed storage at an $\mathrm{MC}$ of $0.1 \mathrm{~g} \mathrm{H}_{2} \mathrm{O} \mathrm{g}^{-1} \mathrm{DW}$ at $20^{\circ} \mathrm{C}$.

\section{ACKNOWLEDGEMENTS}

We would like to thank Universidade do Oeste Paulista (UNOESTE) and the Coordenação de Aperfeiçoamento de Pessoal de Nível Superior (CAPES) (Brazil) Financing Code 001 - PNPD for the scholarship to FLA.

\section{DECLARATION OF CONFLICTS OF INTERESTS}

The authors declare no conflict of interest. The founding sponsors had no role in the design of the study; in the collection, analyses, or interpretation of data; in the writing of the manuscript, and in the decision to publish the results.

\section{AUTHORS' CONTRIBUTIONS}

All authors contributed equally for the conception and writing of the manuscript. All authors critically revised the manuscript and approved the final version.

\section{REFERENCES}

ALVAREZ, V.H. et al. Enxofre. In: Fertilidade do Solo. [s.1.] Novais, R.F. et al., 2007. p.595-644.

ARAÚJO, A.S.F. et al. Textile sludge compost on soybean and wheat seedlings. Pesquisa Agropecuária Brasileira, v.40, p.549-554, 2005. Available from: $<$ https://doi.org/10.1590/S0100204X2005000600004>.

BAHIN, E. et al. Crosstalk between reactive oxygen species and hormonal signalling pathways regulates grain dormancy in barley. Plant, Cell \& Environment, v.34, p.980-993, 2011. Available from: <https://doi.org/10.1111/j.1365-3040.2011.02298.x.>.

BAILLY, C. Active oxygen species and antioxidants in seed biology. Seed Science Research, v.14, p.93-107, 2004. Available from: <https://doi.org/10.1079/SSR2004159>.

BAILLY, C. et al. From intracellular signaling networks to cell death: the dual role of reactive oxygen species in seed physiology.
Comptes Rendus Biologies, v.331, p.806-814, 2008. Available from: <https://doi.org/10.1016/j.crvi.2008.07.022>.

BAILLY, C.; KRANNER, I. Analyses of reactive oxygen species and antioxidants in relation to seed longevity and germination. In: Seed Dormancy. [s.1.] Springer, 2011. p.343-367.

BARBA-ESPÍN, G. et al. Interaction between hydrogen peroxide and plant hormones during germination and the early growth of pea seedlings. Plant, Cell \& Environment, v.33, p.981-994, 2010. Available from: <https://doi.org/10.1111/j.1365-3040.2010.02120. $\mathrm{x}>$.

BARBA-ESPÍN, G. et al. Understanding the role of $\mathrm{H}_{2} \mathrm{O}_{2}$ during pea seed germination: a combined proteomic and hormone profiling approach. Plant, Cell \& Environment, v.34, p.1907-1919, 2011. Available from: $<$ https://doi.org/10.1111/j.1365-3040.2011.02386.x>.

BARBA-ESPÍN, G. et al. Role of $\mathrm{H}_{2} \mathrm{O}_{2}$ in pea seed germination. Plant Signaling \& Behavior, v.7, p.193-195, 2012. Available from: <https://doi.org/10.4161/psb.18881>.

BASKIN, C.C.; BASKIN, J.M. Seeds: ecology, biogeography and evolution of dormancy and germination. (2nd ed.) Academic Press: San Diego, CA, USA. 2014.

BEWLEY, J.D. et al. Seeds: physiology of development, germination and dormancy. [s.1.] Springer, 2013.

BRADFORD, M.M. A rapid and sensitive method for the quantitation of microgram quantities of protein utilizing the principle of protein-dye binding. Analytical Biochemistry, v.72, p.248-254, 1976.

BRASIL. Regras para análise de sementes. Brasília: Ministério da Agricultura, Pecuária e Abastecimento, 2009.

CARDOSO, E.D. et al. Physiological and performance in overcoming dormancy in seeds of Brachiaria brizantha under artificial chemical treatment and aging. Semina-Ciencias Agrarias, p.21-37, 2014. Available from: <https://doi.org/10.5433/1679$0359.2014 \mathrm{v} 35 \mathrm{n} 1 \mathrm{p} 21>$.

CHAHTANE, H. et al. Primary seed dormancy: a temporally multilayered riddle waiting to be unlocked. Journal of Experimental Botany, v.68, p.857-869, 2017. Available from: $<$ https://doi.org/10.1093/jxb/erw377>.

CHEN, K.; ARORA, R. Dynamics of the antioxidant system during seed osmopriming, post-priming germination, and seedling establishment in Spinach (Spinacia oleracea). Plant Science, v.180, p.212-220, 2011. Available from: <https://doi.org/10.1016/j. plantsci.2010.08.007>.

COSTA, C.J. et al. Treatments for seed dormancy release in Brachiaria humidicola (Rendle) Schweick. Pesquisa Agropecuária Tropical, v.41, p.519-524, 2011. Available from: $<$ https://doi.org/10.5216/pat.v41i4.15100>.

CUSTÓDIO, C.C. et al. Imagens digitalizadas na interpretação do teste de tetrazólio em sementes de Brachiaria brizantha. Revista Brasileira de Sementes, v.34, p.334-341, 2012. Available from: $<$ https://doi.org/10.1590/s0101-31222012000200020>.

DIAZ-VIVANCOS, P. et al. Elucidating hormonal/ROS networks during seed germination: insights and perspectives. Plant Cell 
Reports, v.32, p.1491-1502, 2013. Available from: <https://doi. org/10.1007/s00299-013-1473-7>.

EL-MAAROUF-BOUTEAU, H.; BAILLY, C. Oxidative signaling in seed germination and dormancy. Plant Signaling \& Behavior, v.3, p.175-182, 2008. Available from: <https://doi.org/10.4161/ psb.3.3.5539>.

EL-MAAROUF-BOUTEAU, H. et al. Reactive oxygen species, abscisic acid and ethylene interact to regulate sunflower seed germination. Plant, Cell \& Environment, v.38, p.364-374, 2015. Available from: $<$ https://doi.org/10.1111/pce.12371>.

EL-MAAROUF-BOUTEAU, H. et al. ROS signaling in seed dormancy alleviation. Plant Signaling \& Behavior, v.2, p.362 364, 2007. Available from: <https://doi.org/10.4161/psb.2.5.4460>.

FAO. Livestock and the environment. 2018. Disponível em: $<$ http://www.fao.org/livestock-environment/en/>. Accessed: Mar. $12,2019$.

FERREIRA, D.F. Sisvar: a Guide for its Bootstrap procedures in multiple comparisons. Ciência e Agrotecnologia, v.38, p.109112, 2014. Available from: <http://dx.doi.org/10.1590/S1413$70542014000200001>$

FOYER, C.H.; NOCTOR, G. Stress-triggered redox signalling: what's in pROSpect? Plant, Cell \& Environment, v.39, p.951964, 2016. Available from: <https://doi.org/10.1111/pce.12621>.

FOYER, C.H. et al. Viewing oxidative stress through the lens of oxidative signalling rather than damage. Biochemical Journal, v.474, p. 877-883, 2017. Available from :<https://doi.org/10.1042/ BCJ20160814>.

GILL, T. et al. Protein dynamics during seed germination under copper stress in Arabidopsis over-expressing Potentilla superoxide dismutase. Journal of Plant Research, v.125, p.165-172, 2012. Available from: $<$ https://doi.org/10.1007/s10265-011-0421-2>.

GOMES, M.P.; GARCIA, Q.S. Reactive oxygen species and seed germination. Biologia, v.68, p.351-357, 2013. Available from : $<$ https://oi.org/10.2478/s11756-013-0161-y>.

HANUMANTHAPPA, D. et al. Studies on seed dormancy in paddy genotypes. The Ecoscan, v.9, p.261-263, 2015.

HASLEKAS, C. et al. Seed 1-cysteine peroxiredoxin antioxidants are not involved in dormancy, but contribute to inhibition of germination during stress. Plant Physiology, v.133, p.1148-1157, 2003. Available from: <https://doi. org/10.1104/pp.103.025916>.

HAY, F.R. et al. The use of non-saturated lithium chloride solutions for experimental control of seed water content. Seed Science and Technology, v.36, p.737-746, 2008. Available from: $<$ https://doi. org/10.15258/sst.2008.36.3.23>.

IBGE. Censo Agropecuário | IBGE. Available from: < https://www. ibge.gov.br/estatisticas/economicas/agricultura-e-pecuaria/9827censo-agropecuario.html? $=\& \mathrm{t}=\mathrm{O}-$ que-e $>$. Accessed: May, 10, 2020.

KRANNER, I. et al. What is stress? Concepts, definitions and applications in seed science. New Phytologist, v.188, p.655-673, 2010. Available from: <https://doi.org/10.1111 /j.1469-8137.2010.03461.x>.
KUMAR, S.P.J. et al. Seed birth to death: dual functions of reactive oxygen species in seed physiology. Annals of Botany, v.116, p.663668, 2015. Available from: <https://doi.org/10.1093/aob/mcv098>.

LEI, Y.-B. et al. Possible involvement of anti-oxidant enzymes in the cross-tolerance of the germination/growth of wheat seeds to salinity and heat stress. Journal of Integrative Plant Biology, v.47, p.1211-1219, 2005. Available from: <https://doi.org/10.111 1/j.1744-7909.2005.00152.x>.

LIU, Y. et al. $\mathrm{H}_{2} \mathrm{O}_{2}$ mediates the regulation of ABA catabolism and GA biosynthesis in Arabidopsis seed dormancy and germination. Journal of Experimental Botany, v.61, p.2979-2990, 2010. Available from: <https://doi.org/10.1093/jxb/erq125>.

LV, Y.Y. et al. The seed semipermeable layer and its relation to seed quality assessment in four grass species. Frontiers in Plant Science, v.8, p.1175, 2017. Available from: <https://doi. org/10.3389/fpls.2017.01175>.

MARTINS, L.; SILVA, W.R. DA. Efeitos imediatos e latentes de tratamentos térmico e químico em sementes de Brachiaria brizantha cultivar Marandu. Bragantia, v.62, p.81-83, 2003.

MEIMOUN, P. et al. Is gene transcription involved in seed dry after-ripening? PLoS One, v.9, p.e86442, 2014. Available from: $<$ https://doi.org/10.1371/journal.pone.0086442>.

MESCHEDE, D.K. et al. Treatments to overcome Brachiaria brizantha seed dormancy. Revista Brasileira de Sementes, v.26, p.76-81, 2004.

MITTLER, R. ROS are good. Trends in Plant Science, v.22, p.11-19, 2017. Available from: <https://doi.org/10.1016/j. tplants.2016.08.002>

MITTLER, R. et al. Reactive oxygen gene network of plants. Trends in Plant Science, v.9, p.490-498, 2004. Available from: $<$ https://doi.org/10.1016/j.tplants.2004.08.009>.

MORIYA, L.M. et al. Seed vigour better to be assessed by physiological markers rather than expression of antioxidant enzymes in the common bean (Phaseolus vulgaris L.). Australian Journal of Crop Science, v.9, p.30, 2015.

ORACZ, K. et al. ROS production and protein oxidation as a novel mechanism for seed dormancy alleviation. The Plant Journal, v.50, p.452-465, 2007. Available from: <https://doi.org/10.1111/ j.1365-313X.2007.03063.x>.

SAGISAKA, S. The occurrence of peroxide in a perennial plant, Populus gelrica. Plant Physiology, v.57, p.308-309, 1976.

SCHOPFER, P. et al. Release of reactive oxygen intermediates (superoxide radicals, hydrogen peroxide, and hydroxyl radicals) and peroxidase in germinating radish seeds controlled by light, gibberellin, and abscisic acid. Plant Physiology, v.125, p.1591-1602, 2001. Available from: <https://doi.org/10.1104/pp.125.4.1591>.

SIEGEL, B.Z. Plant peroxidases - an organismic perspective. Plant Growth Regulation, v.12, p.303-312, 1993.

SILVA, A.B. et al. Brachiaria seeds germination under different concentration of gibberellin Semina: Ciências Agrárias, v.34, p. 657-662, 2013. Avalaible from: <https:// doi.org/10.5433/1679$0359.2013 \mathrm{v} 34 \mathrm{n} 2 \mathrm{p} 657$. 
SORIGOTTI, L.C.B. et al. Avaliação da dormência de Urochloa humidicola $\mathrm{CV}$. Llanero sob diferentes doses de ácido giberélico e paclobutrazol. Colloquium Agrariae, v.12 especial, p.15-22, 2016. Available from: <https://doi.org/10.5747/ca.2016.v12. nesp. $000165>$.

SUN, Q. et al. Study on the semipermeable characteristics of seven Poaceae seeds. Seed Science and Technology, v.46, p.327-340, 2018. Available from: $<$ https://doi.org/10.15258/sst.2018.46.2.13>

UDSA. USDA ERS - Brazil Once Again Becomes the World's Largest Beef Exporter. Disponível em: < https://www.ers.usda. gov/amber-waves/2019/july/brazil-once-again-becomes-theworld-s-largest-beef-exporter/>. Accessed: May, 10, 2020.

USBERTI, R.; MARTINS, L. Sulphuric acid scarification effects on Brachiaria brizantha, B. humidicola and Panicum maximum seed dormancy release. Revista Brasileira de Sementes, v.29, p.143-147, 2007.

ZEINALABEDINI, M. et al. Breaking seed dormancy in long-term stored seeds from Iranian wild almond species. Seed Science and Technology, v.37, p.267-275, 2009. Available from: $<$ https://doi. org/10.15258/sst.2009.37.2.01>. 